ppi $201502 Z U 4645$

Esta publicación científica en formato digital es continuidad de la revista impresa ISSN-Versión Impresa 0798-1406 / ISSN-Versión on line 2542-3185Depósito legal pp $197402 Z$ U34
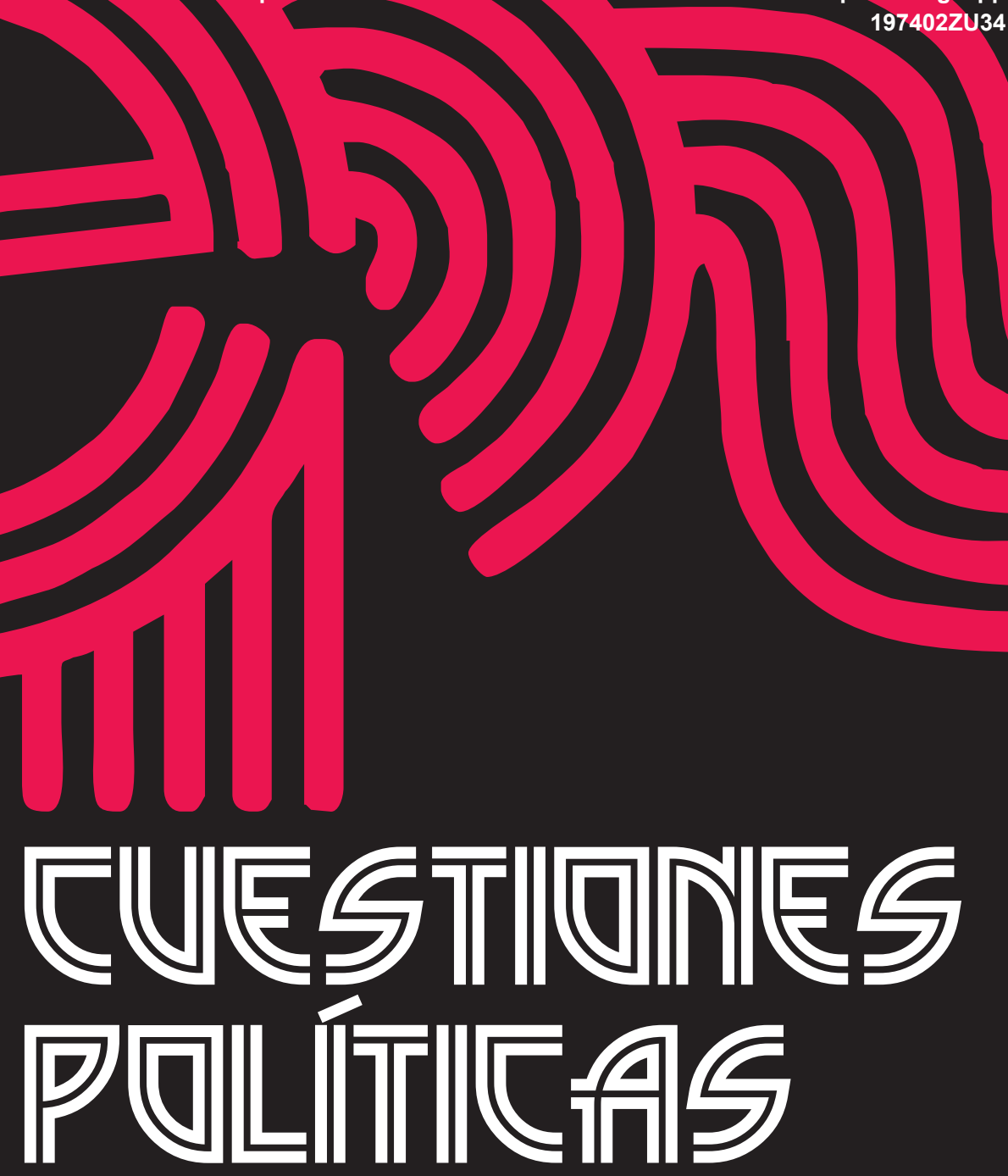

Instituto de Estudios Políticos y Derecho Público "Dr. Humberto J. La Roche" de la Facultad de Ciencias Jurídicas y Políticas de la Universidad del Zulia Maracaibo, Venezuela
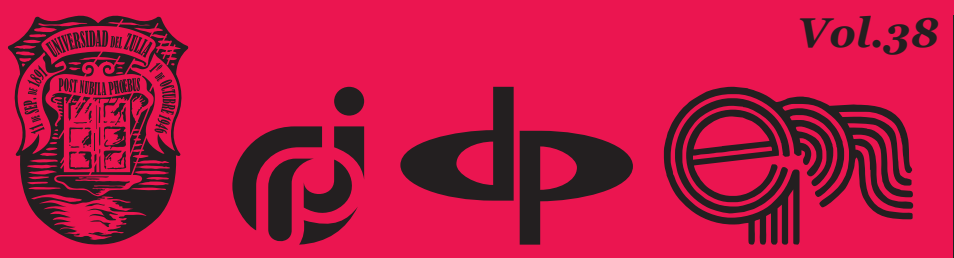

$N^{\circ}$ Especial 2da Parte 2020 


\title{
The problems of organization and legal responsibility (civil and administrative) in the field of telecommunications in Iraq
}

\author{
DOI: https://doi.org/10.46398/cuestpol.382e.29
}

\section{Jaafar Naser Abdulridha * \\ Ghani Ressan Gadder **}

\begin{abstract}
The objective of the investigation is to analyze problems of organization and legal responsibility (civil and administrative) in the field of telecommunications in Iraq. The methodological basis of research consists of dialectical approaches, as well as special methods of studying legal, comparative-legal, structuralfunctional phenomena. Mobile phone use has spread widely among consumers. The mobile phone revolution has transformed lifestyles and livelihood resources with their envelopes to creating new business activities and changing the way people communicate. It is concluded that the use of a mobile phone has many effects, which can be social, physical, sanitary, environmental, or legal. For the latter, we note in Iraq that there is no legal regulation of communications that adheres to the provisions of consignment service providers in their relationship with subscribers. In this way, some communications authorities took on the task of creating the legal, political and administrative conditions by issuing policies that identify, in many cases, the conditions to which the mobile service provider includes in the service contract.
\end{abstract}

Keywords: Iraqi constitution; legal regulation; telecommunications authorities; communications law; consumer protection.

Senior Lecturer, Kazan Federal University, (Faculty of law), Al-Basrah University Republic of Iraq, (Constitutional and administrative law). ORCID ID: https://orcid.org/oooo-0002-7154-1176. Email: Jaafarna124@mail.ru

** Associate Professor, Al-Basrah University, (Faculty of law) Republic of Iraq, (civil law). ORCID ID: https://orcid.org/oooo-0003-1483-4201. Email: alsaadeghani@gmail.com 


\section{Los problemas de organización y responsabilidad legal (civil y administrativa) en el campo de las telecomunicaciones en Irak}

\section{Resumen}

El objetivo de la investigación es analizar algunos problemas de organización y responsabilidad legal (civil y administrativa) en el campo de las telecomunicaciones en Irak. La base metodológica de la investigación está constituida por los enfoques dialécticos, así como por métodos especiales de estudio de fenómenos jurídicos, comparativo-jurídico, estructuralfuncional. El uso del teléfono móvil se ha extendido ampliamente entre los consumidores. La revolución de la telefonía móvil ha transformado los estilos de vida y los recursos de subsistencia con sus contribuciones a la creación de nuevas actividades comerciales y va cambiando la forma en que las personas se comunican. Se concluye que, el uso de un teléfono móvil tiene muchos efectos, que pueden ser sociales, físicos, sanitarios, medioambientales o legales. Para esto último, observamos en Irak que no existe una regulación legal de las comunicaciones que se adhiera a las disposiciones de los proveedores de servicios telefónicos en su relación con los suscriptores. De esta manera, algunas autoridades de comunicaciones adoptaron la tarea de crear las condiciones jurídicas, políticas y administrativas emitiendo directivas que identifican, en muchos casos, las condiciones arbitrarias que el proveedor de servicios de telefonía móvil incluye en el contrato de servicio.

Palabras clave: constitución iraquí; regulación legal; autoridades de telecomunicaciones; ley de comunicaciones; defensa del consumidor.

\section{Introduction}

Article (40) of the Constitution of the Republic of Iraq for the year 2005 stipulates that "(freedom of communication and postal, telegraphic, telephone, electronic and other correspondence is guaranteed and it is not permissible to monitor and eavesdrop on them or reveal them except for legal and security necessity and by judicial decision). As for the Iraqi Wireless Communications Law No. 159 of 1980, it did not lay down the legislative basis for legal liability arising from the installation of mobile phone towers, nor did it set the controls for the import of such devices that are supposed to be subject to quality control to know the extent of their seriousness as a dangerous commodity according to the Standardization and Quality Control Law For the year 1979. Instructions No. 1 of 2007 


\section{Jaafar Naser Abdulridha y Ghani Ressan Gadder \\ 372 \\ The problems of organization and legal responsibility (civil and administrative) in the field of}

concerning the prevention of nonionizing radiation issued by the main and secondary constellations of mobile phones in Iraq. These instructions were issued according to Article 24 of the Iraqi Environmental Protection and Improvement Law No. 3 of 1997, and Article 1 / First of them stipulated the definition of non-ionizing radiation emitted by the main and secondary constellations of mobile phones as electromagnetic radiation located on low frequencies starting from 10 megahertz and above, such as radiation Launched from major broadcasting stations and antennas for mobile phones.

\section{Methods}

The methodological basis of the research is constituted by the general scientific dialectic methods of cognition, and deduction, systemic methods, as well as special methods of studying legal phenomena, comparative-legal, structural-functional, etc.

\section{Results and Discussion}

The purpose of issuing these instructions is to protect living organisms and other elements of the environment from non-ionizing radiation and their biological effects according to Article 2 of these instructions. Article 4 dealt with that the companies that own the systems covered by the provisions of these instructions are required to provide devices for measuring the exposure values for the general public in accordance with the applicable Environmental Protection and Improvement Law.

They are also required to transfer to official approvals from the competent authority to practice the activity according to the forms attached to these instructions and to provide a report on the environmental impact according to Article 18 of the Iraqi Environmental Improvement Law of 1997. In addition, penalties and precautionary measures may be imposed on the legal person, including companies, factories and establishments, as companies and institutions have been granted, as the law has given the General Director of the Environment or whoever represents him a warning of any facility or laboratory with polluting effects of the environment to remove the influencing factor within ten days from the date of notification and in the event of failure Responding to the warning, the general manager can temporarily suspend work or shut down the company causing the damage for a period of no more than a month, and a recommendation can be made to the Environmental Protection Council to issue a permanent closure order (Fisher, 2009). 
Here, the organized and racing position in the Iraqi legislation to regulate liability arising from the damages caused by mobile devices is noted. And when the mobile phone comapanies violate the legal procedures, they are subject to penalties in the form of a fine and confiscation, and the company's cessation of its activity and its dissolution (Al-Din Ali, 2016).

However, after 2003, a number of legislations appeared to confront mobile phone crimes and regulate their work such as the Law on the Protection of Iraqi Products, the Money Laundering Law 2004 and the Law for the Protection and Improvement of the Environment 2012, as well as the regulations and instructions issued related to radiation protection emitted from the towers of the communication companies represented in instructions No. 1 of 2007 canceling the instructions of the Ministry of Environment For the year 2010.

The development taking place in various fields of human life and modern technology that have occurred to him, helped him a lot and provided him with many of the benefits and facilities that he needs in most of his life, but this development that occurred in the technology field has negative side effects despite his great benefit. Waste is industries and radiation. Those that arise from establishments with industrial activity adversely affect the neighborhood environment and make people's lives vulnerable to imminent danger.

These radiations are among the most important sources of a third of the environment, as they are very dangerous and widespread in the earth, and their danger has increased after the discovery of nuclear and atomic energy and uranium enrichment, in addition to the large number of nuclear tests, and all of this would affect the person (the neighbor) and his life (Shi and Warwick, 2018).

Through this, we understand that these emissions from industrial and military wastes pose a great danger to human life and are considered uncommon, because of their impact on the injury of many dangerous diseases, and this justifies those who have been harmed by them to seek compensation and remove those harms if It was possible and the Qatar Radiation Protection Law No. 31 of 2002 was issued.

The Iraqi Environmental Protection Law has paid attention to radiation pollution of the air, and this interest appears clear in the texts and paragraphs, as Article (32) of the same law indicated the obligation of the person responsible for environmental damage to compensation and its removal and return the case to what it was before the damage occurred, and also gave the article ( 33 ) The Minister has the right to close installations that result in environmental damage that leads to unfamiliar neighborhood harms for a period of thirty days, which can be extended until the violation caused by those facilities. 
The administrative license is defined as the permission issued by the competent authorities to practice a specific work or activity or the opening of a factory or the like, which may not be practiced without this permission (Liu and Tronchetti, 2019), and it is thus considered one of the means of intervention of the state in the individual actions or activities that could result from it. Damage to the other mobile phone towers (Al-Mousawi, 2011; Glenn and White, 2007), especially those that would lead to harm to people or the threat of danger to obtaining an administrative license in order to conduct work or industrial or commercial activity , as well as owners of buildings and before proceeding to construct them they obtain a license Building, which would give the administration a prior opportunity to monitor work and see if the building conforms to the conditions in the general rules (Liu and Tronchetti, 2019) .

It is worth noting that the nature of the administrative license in general is of an attribute in kind, meaning that it relates to the licensed place and not to the owner of the store, as the issue of consideration here is the licensed activity and the conditions of its practice and conditions and the consequences thereof, and it follows from the kind attribute of the administrative license that it is possible Assignment from the licensee to another person through assignment.

The Iraqi legislator did not address the issue of paying the responsibility of the owner (the neighbor causing damage) through administrative licensing, nor did the 1986 draft of the Iraqi civil law deal with this issue, and the explanations of the civil law did not explicitly indicate the extent to which the person responsible for the harmful act can pay the administrative license, but They cited some statements that have the meaning of inadmissibility of payment with an administrative license A part of the commentator (Akamangwa, 2017).

dealt with the issue of paying the administrative license, but from the affected neighbor (the plaintiff), as it went to the conclusion that the administrative license granted to the owner of the factory or industrial facility that resulted in harm to the neighbor does not prevent the affected neighbor in the request to remove those obscene harms inflicted on him and another side (Hider, 1971). Dealt with this issue by the neighbor causing the damage, as he said that the administrative license does not prevent the owner from assuming responsibility for the harms caused to the neighbor.

We conclude from the statements of some Iraqi civil law commentators that it is not permissible for the owner (the one who caused the damage) to pay his responsibility by saying that he obtained an administrative license to practice his activity that resulted in harm to others. The Iraqi legislator did not address the issue of precedence in possession or exploitation, except that it is understood through the text of Article (1051/3) of the Iraqi Civil Law that precedence in ownership or exploitation would protect the owner 
from assuming his responsibility for the subsequent harms of his neighbor, as this article stipulated that (If one is acting in his possession lawfully, then another comes and creates a constructive and harmful part of his side, then he must pay the harm himself).

The error as a general rule is a basic element in the legal responsibility for the damage of mobile phones, and in the case of its absence there is neither responsibility nor compensation for the damage that afflicted the victim, and the error in civil liability as one of its pillars is stipulated in all civil regulations with different expressions on it (Al-Mousawi, 2011), and the person causing the damage is obligated Compensation for the aggrieved person during his life, and this obligation is transferred to his heirs after his death, as they are obligated to pay the amount of compensation from his estate before dividing them to them (Dong, and Zhu, 2019), so the rule is that "(there is no legacy except after paying the debts)" (Mark, 1988), that is, the debtor's legacy is transferred as soon as he dies The right of my eyes to the deceased debtors creditors authorizes them to track and collect their debts from them under the hands of any heir or whoever has the last disposed to them as long as the debt exists without this heir if the creditor makes the lawsuit claim to pay the debt expiry for him, and the heirs are not in solidarity in Pay off the debt except.

It is not enough to arrange solidarity responsibility for an error, but there must be one harm that results from these errors. Intentional harm is meant to be the damage caused by each of the multiple officials is the same damage that resulted from the action of each of them (Al-Thanoon and AlDarar, 1991), in the case of multiple owners of the signs in the sense that the damage is of the same nature represented by a specific physical injury, or damage to a specific thing, from Where if every mistake causes harm to a person in a specific area, he does not ask in solidarity with another person whose mistake caused a different damage ( Al-Din Ali, 2016).

\section{Conclusions}

To summarize the above, we can conclude that defining civil, administrative, and criminal liability in the field of protecting and using mobile phones is one of the main problems in the Iraqi legal system, and that detection and investigation of crimes in the field of computer information and high technology remains one of the most difficult tasks of criminal investigation and Preliminary investigation. This is linked to a number of problems, including the lack of adequate monitoring of the investigation into judicial practice. 


\section{Jaafar Naser Abdulridha y Ghani Ressan Gadder \\ 376 \\ The problems of organization and legal responsibility (civil and administrative) in the field of}

In the field of cybercrime, the lack of experience of local specialists in this field, and finally, the general lack of scientific basis and methodological recommendations regarding tactics and methodology that have been tested in the practice of investigating crimes in the field of computer information and high technologies.

And due to the lack of legislative treatment regarding determining the responsibility arising from the import of mobile devices and their severity, we suggest that the Iraqi legislator legislates the Communications and Media Law, and it stipulates that the information and the Communications Authority are obligated to take upon themselves theimposition of restrictions on the import of mobile devices for all telecommunications companies and take them It shoulders. We also suggest that the Iraqi legislator stipulates in the Iraqi Consumer Protection Law No. 1 of 2010 the right of mobile phone consumers to form associations or institutions so that mobile phone subscribers can gather in one place according to the geographical area to confront service providers. In the event of health damage or radiation affecting them due to the damage of imported devices that lead to damage in the consumer category.

\section{Acknowledgements}

The work is performed according to the Russian Government Program of Competitive Growth of Kazan Federal University.

\section{Bibliographic References}

AKAMANGWA, Ngwatung. 2017. "Regulatory Influences on Environmental Protection: Why Shipping Companies Comply and When They Don't" In: Ocean Development \& International Law. Vol. 48, No. 02, pp. 158180 .

AL-DIN, Ali, Y. 2016. "Civil Liability Resulting from Infringement of Persons in the English Law (An Analytical Comparative Study with raqi Law)” In: Journal of Legal Sciences. Vol. 31, No. 1, pp. 44-56.

AL-MOUSAWI, H. 2011. Harmful Damage and Provisions of Warranty for him in Neighborhood Relations. Master Thesis in Private Civil Law, University of Karbala-College of Law. Karbala, Iraq. 
AL-THANOON, H; AL-DARAR, A. 1991. In the Duplication or Unity of Civil Liability and the Question of Goodness. Cairo University Press. Cairo, Lebanon.

DONG, Bingying; ZHU, Ling. 2019. "Civil Liability and Compensation for Damage in Connection with the Carriage of Hazardous and Noxious Substances: Chinese Perspective"In: Ocean Development\&International Law. Vol. 50, No. 2-3, pp. 209-224.

FISHER, Liz. 2009. "Environmental Law, Policy and Economics: Reclaiming the Environmental Agenda. By Nicholas Ashford and Charles Caldart" In: Journal of Environmental Law. Vol. 21, No. 2, pp. 380-382.

GLENN, Helen; WHITE, Hannah. 2007. "Legal Traditions, Environmental Awareness, and a Modern Industry: Comparative Legal Analysis and Marine Aquaculture" In: Ocean Development \& International Law. Vol. 38, No. 1-2, pp. 71-99.

HIDER, S.N. 1971. The mediator in explaining the new civil law. Al-Maarif Press. Baghdad, Iraq.

IRAQI LAW OF PROTECTION AND IMPROVEMENT OF THE ENVIRONMENT. 2009. Baghdad, Iraq. Available online. In: https:// www.ilo.org/dyn/natlex/natlex4.detail?p_isn=89060\&p_lang=en. Consultation date: 10/12/2019.

LIU, Hao; TRONCHETTI, Fabio. 2019. "Regulating Near-Space Activities: Using the Precedent of the Exclusive Economic Zone as a Model?” In: Ocean Development \& International Law. Vol. 50, No. 2-3, pp. 91-116.

MARK, S. 1988. Al-Wafi in Explaining the Civil Law, Part 2, in Obligations, Volume Two, On Harmful Act and Civil Responsibility. Section One, in General Provisions, 5th Edition, Al-Salam Press. Baghdad, Iraq.

SHI, Yubing; WARWICK, Gullet. 2018. "International Regulation on LowCarbon Shipping for Climate Change Mitigation: Development, Challenges, and Prospects" In: Ocean Development \& International Law. Vol. 49, No. 2, pp. 134-156.

THE EXECUTIVE REGULATIONS OF THE DECREE-LAW NO 31 OF THE YEAR 2002 CONCERNING RADIATION PROTECTION. 2002. Available online. In: http://inis.iaea.org/search/search.aspx?orig $\mathrm{q}=\mathrm{RN}: 38085260$. Consultation date: 10/12/2019. 

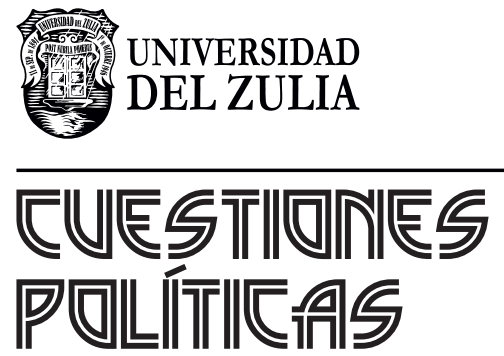

Vol.38 NEspecial

Esta revista fue editada en formato digital y publicada en diciembre de 2020, por el Fondo Editorial Serbiluz, Universidad del Zulia. Maracaibo-Venezuela 